Research Note

\title{
Heat Dosage and Oviposition Depth Influence Egg Mortality of Two Common Rangeland Grasshopper Species
}

\author{
David H. Branson ${ }^{1}$ and Lance T. Vermeire ${ }^{2}$ \\ Authors are ${ }^{1}$ Research Entomologist, USDA-ARS Northern Plains Agricultural Research Laboratory, Sidney, MT 59270, USA; and ${ }^{2}$ Rangeland Ecologist, \\ USDA-ARS Fort Keogh Livestock and Range Research Laboratory, Miles City, MT 59301, USA.
}

\begin{abstract}
Rangeland fire is a common naturally occurring event and management tool, with the amount and structure of biomass controlling transfer of heat belowground. Temperatures that grasshopper eggs are exposed to during rangeland fires are mediated by species-specific oviposition traits. This experiment examined egg mortality in two slant-faced grasshopper species with differing oviposition traits, namely Aulocara elliotti (Thomas) and Opeia obscura (Thomas). We hypothesized that A. elliotti egg mortality would increase with fire intensity because the shallow egg location below the soil surface would result in exposure to higher temperatures, and that the deeper O. obscura eggs would not be affected by fire intensity. Fire intensity did not significantly affect the mortality of O. obscura eggs, with very low mortality in all treatments. Fire intensity significantly affected mortality of $A$. elliotti eggs, which are laid in shallow egg pods with the midpoint of the egg clutch at a depth of $\sim 0.825$ $\mathrm{cm}$. Aulocara elliotti egg mortality increased with higher levels of heat application, with $79 \%$ egg mortality in the $4500 \mathrm{~kg} \cdot \mathrm{ha}{ }^{-1}$ heat treatment. Heat effects on A. elliotti egg mortality were similar to those previously observed for another shallow-egg-laying species. Limited research has examined if rangeland fires reduce population densities of specific economically important grasshopper species. The results from this experiment indicate that grasshopper species with the midpoint of the egg pod less than $1 \mathrm{~cm}$ below the surface are likely in general to be vulnerable to fire-induced egg mortality during rangeland fires.
\end{abstract}

Key Words: Aulocara elliotti, bigheaded grasshopper, fire, grassland, obscure grasshopper, Orthoptera

\section{INTRODUCTION}

Grasshoppers are often the most economically important insects in North American rangeland systems (Branson et al. 2006). Rangeland fire is a common naturally occurring event and management tool (Whelan 1995; Pyne et al. 1996), with fire effects on grasshopper assemblages differing between ecosystems (Branson et al. 2006). Positive and negative population changes have been attributed to direct mortality of eggs, nymphs, or adults (Bock and Bock 1991; Vermeire et al. 2004; Branson and Vermeire 2007), as well as fire-induced changes in host plant quality and plant composition (Evans 1984; Porter and Redak 1996; Joern 2004; Vermeire et al. 2004). The timing and intensity of a fire can be important, particularly relative to the developmental stages of species present (Branson 2005; Branson et al. 2006; Branson and Vermeire 2007).

Shallow subsurface temperatures in rangeland fires can reach levels considered lethal for most organisms (Wright and Bailey 1982; Whelan 1995), with the amount and structure of combustible biomass controlling temperatures and duration of heat (Pyne et al. 1996). Rangeland grasshopper species oviposit eggs at depths ranging from just below to greater than $5 \mathrm{~cm}$ below the soil surface, with the size and orientation of egg

Correspondence: David H. Branson, USDA-ARS Northern Plains Agricultural Research Lab, 1500 N Central Ave, Sidney, MT 59270, USA. Email: dave.branson@ars.usda. gov

Manuscript received 30 September 2011; manuscript accepted 12 July 2012

(c) 2013 The Society for Range Management pods also varying (Onsager and Mulkern 1963; Pfadt 2002). As a result, temperatures that eggs are exposed to during rangeland fires are mediated by species-specific oviposition traits (Branson and Vermeire 2007). In the first study to link changes in grasshopper populations following fire to belowground egg mortality, Branson and Vermeire (2007) tested the hypothesis that heat exposure during rangeland fire was the mechanism responsible for observed postfire reductions in Ageneotettix deorum (Scudder) densities. Fires simulating a vegetative biomass of at least $3100 \mathrm{~kg} \cdot \mathrm{ha}^{-1}$ significantly reduced egg survival of $A$. deorum, which lays egg pods horizontally just below the soil surface, but not of Melanoplus sanguinipes (Fabricius), which lays deeper, vertically oriented egg pods (Branson and Vermeire 2007). It is unknown if species other than $A$. deorum have the potential to be managed with fire (Branson and Vermeire 2007).

To enhance predictions of grasshopper population responses following fire, the importance of fire-mediated egg mortality needs to be examined in species with egg pod depths intermediate between A. deorum and M. sanguinipes (Branson and Vermeire 2007). This experiment examined egg mortality in two such grasshopper species in the Gomphocerine subfamily, Aulocara elliotti (Thomas) and Opeia obscura (Thomas) with exposure to simulated fall fire to prediapause eggs in soil. Aulocara elliotti was examined because Pfadt (2002) hypothesized it should be exposed to a wide range of soil temperatures due to the relatively shallow depths where the eggs are located. Opeia obscura was examined because populations were observed to decline following a prescribed fire (Branson and Vermeire, unpublished data, 2003-2006). We 
hypothesized that $A$. elliotti egg mortality would increase with fire intensity and that the deeper O. obscura eggs would not be affected by fire intensity.

\section{METHODS}

The two Gomphocerine (slant-faced) grasshoppers examined are gramnivorous egg-overwintering species (Pfadt 2002). A. elliotti is an economically important species that is frequently the dominant species in rangeland grasshopper outbreaks (Pfadt 2002). It is an early-hatching species which lays egg pods of seven to nine eggs in the top $1.25 \mathrm{~cm}$ of soil (Pfadt 2002). The shallow average egg depth of $\sim 0.825 \mathrm{~cm}$ likely exposes eggs to warm summer temperatures and facilitates the early hatching phenology (Kemp and Sanchez 1987; Pfadt 2002). O. obscura is a late-hatching species that typically does not reach outbreak densities (Pfadt 2002). It lays vertically oriented egg pods $\sim 2.2 \mathrm{~cm}$ long, with an average of 8 to 10 eggs (Pfadt 2002). A froth plug at the anterior end of the egg pods results in the posterior end being $\sim 2.2 \mathrm{~cm}$ to $2.5 \mathrm{~cm}$ below the surface. Pfadt (2002) speculated that the deeper location of O. obscura eggs should reduce exposure to temperature extremes compared to those of A. elliotti and A. deorum.

Methods followed Branson and Vermeire (2007), which provides more detailed methodological descriptions. Intact soil cores were collected at a mixed-grass prairie in western North Dakota and placed in cups as oviposition sites. Adult grasshoppers were caught in the field and placed in insect cages containing oviposition cups. The cages were maintained at $30^{\circ} \mathrm{C}$ with a $16-\mathrm{h} / 8$-h light/dark cycle and newly caught individuals were added to maintain densities. Grasshoppers were fed a combination of grasses clipped on nearby rangeland, wheat bran, and greenhouse-grown western wheatgrass (Pascopyrum smithii [Rydb.] Á. Löve) and blue grama (Bouteloua gracilis [Willd. ex Kunth] Lag. ex Griffiths). Oviposition cups remained in rearing cages for $\sim 2.5 \mathrm{wk}$ before being removed. After removal, cups were watered and remained at $30^{\circ} \mathrm{C}$ for 2 wk to allow development of eggs to their maximum prediapause state. They were subsequently maintained at $21^{\circ} \mathrm{C}$ until the simulated fire. To ensure consistent soil moisture levels, no moisture was applied for $2 \mathrm{wk}$ prior to the simulated fire. Excess plant debris was removed prior to treatment to limit heat variation among replications.

By examining a range of realistic heat treatments, predictions can be made regarding fuel loads associated with egg mortality. Heat treatments included a nonburned control and simulated grassland fuel loads of $3100 \mathrm{~kg} \cdot \mathrm{ha}^{-1}$ and 4500 $\mathrm{kg} \cdot \mathrm{ha}^{-1}$. Branson and Vermeire (2007) examined an additional treatment simulating a $1700 \mathrm{~kg} \cdot \mathrm{ha}^{-1}$ fire, but observed no effect on egg mortality in $A$. deorum, which lays egg pods at a slightly shallower depth than A. elliotti. Simulation methods followed the approach of Campbell et al. (1995), and were designed to match time-temperature profiles observed during rangeland fires in mixed prairie (Wright et al. 1976). The heat source was a propane heater placed $\sim 5 \mathrm{~cm}$ above the soil surface and pointed downward over a lab bench. Times required to approximate time-temperature curves observed for fuel loads of $3100 \mathrm{~kg} \cdot \mathrm{ha}^{-1}$ and $4500 \mathrm{~kg} \cdot \mathrm{ha}^{-1}$ were $23 \mathrm{~s}$ and $46 \mathrm{~s}$ as developed by Branson and Vermeire (2007). Fuel loads simulated were within the range of values for standing crop and litter mass observed on grasslands throughout the distributions of A. elliotti and O. obscura (Sims et al. 1978; Sims and Singh 1978; Pfadt 2002). Heat treatments were applied to all oviposition cups within $2 \mathrm{~h}$. Water was added 1 wk after treatment. After $1 \mathrm{wk}$ at $21^{\circ} \mathrm{C}$, the cups were placed at $\sim 8^{\circ} \mathrm{C}$ for 3 mo to break diapause (Henry 1985). Cups were then watered and placed at $30^{\circ} \mathrm{C}$ with a $16-\mathrm{h} / 8$-h light/dark cycle. Screen-top cages were placed on each cup. Hatching grasshoppers were removed and counted daily. After no grasshoppers hatched for $10 \mathrm{~d}$, egg pods were removed from the oviposition cups and dissected to determine numbers of unhatched eggs. For each species, 12 replicate cups were randomly assigned to each treatment.

Egg mortality was used to assess treatment effects. As some cups in all treatments had a significant proportion of hatchlings that were out of their egg case but did not reach the surface in the A. elliotti experiment, egg mortality was calculated by counting the number of unhatched eggs with the embryo still inside the egg case and dividing by the total number of hatchlings and unhatched eggs in each cup. Embryos outside the egg case but not reaching the surface were assumed to have survived the fire and were not included in the mortality category. As consistent oviposition could not be controlled, only oviposition cups that contained at least 10 individual eggs were included in the statistical analysis. This led to the removal of 16 cups for A. elliotti and 10 cups for O. obscura. Nonparametric Kruskal-Wallis analysis of variance (ANOVA) was used to examine if burning affected the proportion of eggs that hatched. When the Kruskal-Wallis ANOVA was significant, nonparametric Mann-Whitney pairwise comparisons were used to relate grassland fuel loads with the proportion of hatching eggs. Box plots with median and quartile values were used to graphically represent the egg hatch data. Statistical analyses were conducted using Systat 12 (Systat Software 2007).

\section{RESULTS AND DISCUSSION}

Fire intensity did not significantly affect $O$. obscura egg mortality $\left(\chi_{2}^{2}=2.32, P=0.31\right.$; Fig. 1). Because O. obscura eggs are typically located between $\sim 1.6 \mathrm{~cm}$ and $2.2 \mathrm{~cm}$ below the surface (Pfadt 2002), the eggs were far enough below the surface to avoid lethal temperatures with a simulated grassland fuel load of $4500 \mathrm{~kg} \cdot \mathrm{ha}^{-1}$. The lack of a significant effect at a simulated $4500 \mathrm{~kg} \cdot \mathrm{ha}^{-1}$ biomass is similar to M. sanguinipes, which lays slightly deeper egg pods (Branson and Vermeire 2007). The results from the simulated fire treatments indicate that reductions in O. obscura following prescribed fires (Branson and Vermeire, unpublished data, 2003-2006) would result from a mechanism other than elevated temperatureinduced egg mortality.

Mortality of $A$. elliotti eggs increased with fire intensity $\left(\chi_{2}^{2}=12.948, P=0.002\right.$; Fig. 1$)$, although uneven A. elliotti oviposition patterns in egg cups led to lower effective replication levels. Based on pairwise comparisons, egg mortality was greater with additional heat application (Fig. 1). Egg mortality was greater in the $3100 \mathrm{~kg} \cdot \mathrm{ha}^{-1}$ heat treatment than 


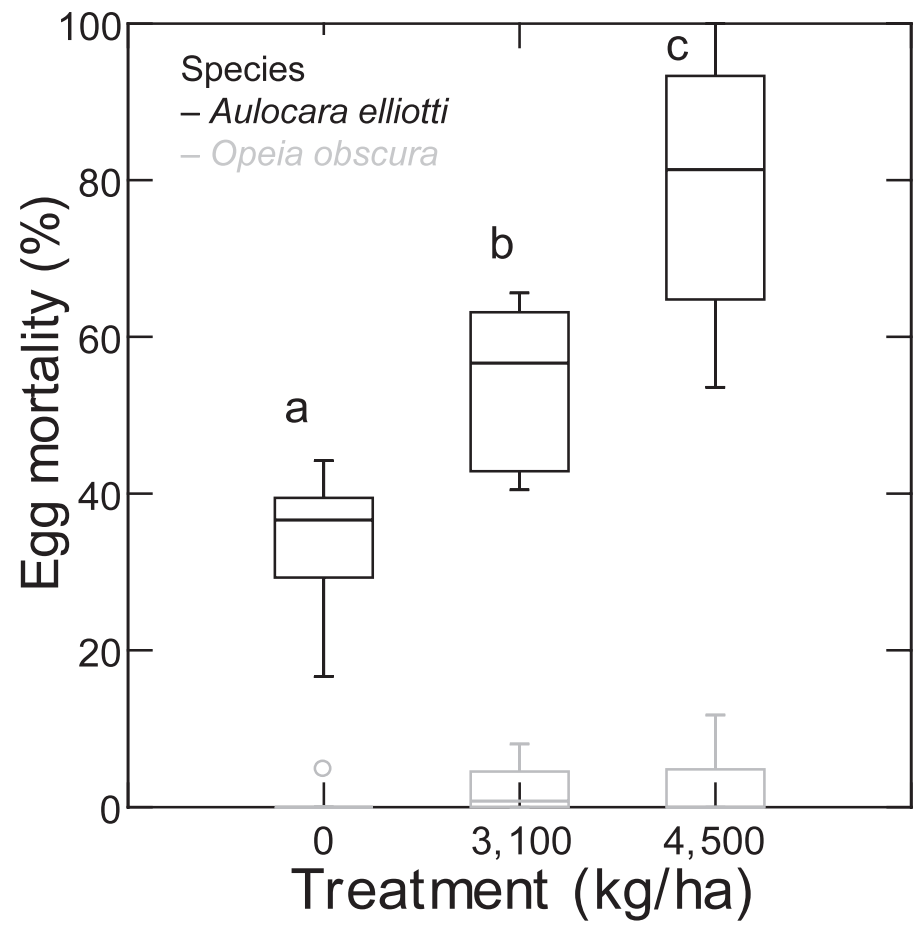

Figure 1. Percentage of egg mortality for Opeia obscura and Aulocara elliotti (median with 25\% and 75\% quartiles and upper and lower inner fences) in treatments simulating fire fuel loads of $0 \mathrm{~kg} \cdot \mathrm{ha}^{-1}$ (control), $3100 \mathrm{~kg} \cdot \mathrm{ha}^{-1}$, and $4500 \mathrm{~kg} \cdot \mathrm{ha}^{-1}$. Letters indicate significant treatment differences $(P<0.05)$.

in the untreated control $(P=0.003)$, increasing from $34 \%$ to $54 \%$. Egg mortality increased to $79 \%$ in the $4500 \mathrm{~kg} \cdot \mathrm{ha}^{-1}$ heat treatment (Fig. 1), and was significantly higher than the untreated control $(P=0.008)$ and $3100 \mathrm{~kg} \cdot \mathrm{ha}^{-1}$ treatment $(P=0.047)$. The pattern of heat effects on $A$. elliotti egg mortality was similar to those observed for $A$. deorum by Branson and Vermeire (2007), although egg mortality was not as great for $A$. elliotti. This result is consistent with the slightly deeper oviposition depth in A. elliotti.

Species-specific oviposition traits determined the effects of simulated fire intensity on egg mortality in the two species of Gomphocerine grasshoppers examined. No significant egg mortality was observed in O. obscura, for which eggs are typically located between $\sim 1.6 \mathrm{~cm}$ and $2.2 \mathrm{~cm}$ below the surface. Significant egg mortality occurred at both simulated fire levels in A. elliotti, which lays much shallower egg pods. Rangeland grasshopper species often exhibit strong oviposition preferences, which could influence the importance of fireinduced egg mortality. A. elliotti appears to be highly selective in regard to oviposition (Fisher 1992), which likely contributed to a number of oviposition cups without eggs pods. In particular, the middle of grass clumps is not a preferred oviposition site for A. elliotti (Kemp and Sanchez 1987; Fisher 1992).

Oviposition preference may differ between grassland habitat types. Fisher (1992) found A. elliotti laid more egg pods on the south sides of crested wheatgrass clumps, whereas Pfadt (2002) and Capinera and Sechrist (1982) noted oviposition in bare areas. If $A$. elliotti preferentially oviposited in bare areas, egg mortality rates following rangeland fire could be lower than indicated by the relationships from this laboratory study. The ability of grasshoppers to avoid fire by selecting bare ground would depend on size of bare patches, distance of oviposition sites from areas with fuel, and characteristics of the surrounding fuel and weather that affect heat production and transfer. No recent studies examining fire effects on grasshoppers in the northern Great Plains have been conducted when A. elliotti was abundant, so the predicted relationships between standing biomass and egg mortality need to be field-verified. Importantly, rangeland fire intensity and behavior are heterogeneous and respond to relative humidity, air temperature, wind, and atmospheric stability (Pyne et al. 1996). Transfer of heat into the soil is also negatively affected by water content (Campbell et al. 1995; Whelan 1995; DeBano et al. 1998), indicating that fires conducted with higher levels of soil moisture would likely lead to lower levels of egg mortality than observed in this laboratory experiment. Species-specific differences may exist in terms of egg susceptibility to heat (Parker 1930), but controlled experiments are lacking.

Both this study and that of Branson and Vermeire (2007) examined the effect of simulated fall fire on prediapause eggs. Prescribed fire is also commonly applied during spring. Egg mortality could vary with season of fire to the extent that weather and fuel conditions affect heat dosage, and based on the timing of fire relative to egg hatching dates. Fuel moisture increases with the advance of new plant growth during spring and greater fuel moisture will reduce combustion, heat, and therefore, egg mortality. Many eggs could also hatch before a late spring fire. Rather than reducing mortality, late spring fire would likely shift the cause from egg to nymph mortality, because young nymphs are wingless and would be unable to escape flames. Burning could lead to a variety of indirect impacts that were not assessed in this study, such as earlier hatching resulting from increased soil temperatures following fire. Earlier hatching may partially compensate for losses through improved reproduction (Evans 1984), but reproductive improvement would have to be substantial to overcome mortality rates we have observed. Data are limited; however, the only direct comparison of fall and spring fire effects on grasshoppers of which we are aware (Vermeire et al. 2004) observed similar reductions of a shallow-egg species, $A$. deorum, with fall and spring (mid-April) fire.

\section{MANAGEMENT IMPLICATIONS}

Vermeire et al. (2004) and Branson et al. (2006) suggested that fire has potential for use as a preventative grasshopper pest management tactic that utilizes natural ecological processes, but little research has examined if rangeland fire can be used to reduce population densities of economically important grasshopper species. The results from this experiment indicate that an economically important grasshopper species laying deeper egg pods than $A$. deorum, which was previously shown to be vulnerable to fire-induced egg mortality (Branson and Vermeire 2007), is also vulnerable to egg mortality during rangeland fires. Therefore, it appears likely that the subset of rangeland grasshopper species in western North America with a midpoint egg pod depth of less than $1 \mathrm{~cm}$ have the potential to have their populations reduced through burning, particularly if they oviposit near vegetative cover. 


\section{ACKNOWLEDGMENTS}

We thank Mo O'Mara and Nicole Davidson for their help with this experiment. Thanks to John Gaskin for helpful comments on an earlier draft of this manuscript.

\section{LITERATURE CITED}

Bock, C. E., AND J. H. Bock. 1991. Response of grasshoppers (Orthoptera: Acrididae) to wildfire in a southeastern Arizona (USA) grassland. American Midland Naturalist 125:162-167.

Branson, D. H. 2005. Effects of fire on grasshopper assemblages in a northern mixedgrass prairie. Environmental Entomology 34:1109-1113.

Branson, D. H., A. Joern, and G. A. Sword. 2006. Sustainable management of insect herbivores in grassland ecosystems: New perspectives in grasshopper control. Bioscience 56:743-755.

Branson, D. H., and L. T. Vermelre. 2007. Grasshopper egg mortality mediated by oviposition tactics and fire intensity. Ecological Entomology 32:128-134.

Campbell, G. S., J. D. Jungbauer, K. L. Bristow, and R. D. Hungerford. 1995. Soiltemperature and water-content beneath a surface fire. Soil Science 159:363374.

Capinera, J. L., and T. S. Sechrist. 1982. Grasshoppers (Acrididae) of Colorado. Fort Collins, C0, USA: Colorado State University Experiment Station. Bulletin 584S. $161 \mathrm{p}$.

DeBano, L. F., D. G. Neary, and P. F. Ffollott. 1998. Fire effects on ecosystems. New York, NY, USA: John Wiley \& Sons. 333 p.

Evans, E. W. 1984. Fire as a natural disturbance to grasshopper assemblages of tallgrass prairie. Oikos 43:9-16.

FISHER, J. R. 1992. Location of egg pods of Aulocara elliotti (Orthoptera, Acrididae) in a field of crested wheatgrass in Montana. Journal of the Kansas Entomological Society $65: 416-420$.

Henry, J. E. 1985. Melanoplus spp. In: P. Singh and R. F. Moore [EDs.]. Handbook of insect rearing. Amsterdam, Netherlands: Elsevier Science Publishers. p. 451464.
Joern, A. 2004. Variation in grasshopper (Acrididae) densities in response to fire frequency and bison grazing in tallgrass prairie. Environmental Entomology 33:1617-1625.

Kemp, W. P., and N. E. Sanchez. 1987. Differences in postdiapause thermal requirements for eggs of two rangeland grasshoppers. Canadian Entomologist 119:653-661.

OnsAger, J. A., And G. B. Mulkern. 1963. Identification of eggs and egg-pods of North Dakota grasshoppers (Orthoptera: Acrididae). North Dakota Agricultural Experiment Station Bulletin 446:3-47.

PARKER, J. R. 1930. Some effects of temperature and moisture upon Melanoplus mexicanus mexicanus Saussure and Camnula pellucida Scudder (Orthoptera). University of Montana Agricultural Experiment Station Bulletin 223:1-132.

PFADT, R. E. 2002. Field guide to common western grasshoppers. 3rd ed. Wyoming Agricultural Experiment Station Bulletin 912. 288 p.

Porter, E. E., and R. A. Redak. 1996. Short-term recovery of the grasshopper communities (Orthoptera: Acrididae) of a California native grassland after prescribed burning. Environmental Entomology 25:987-992.

Pyne, S. J., P. L. Andrews, and R. D. Laven. 1996. Introduction to wildland fire. 2nd ed. New York, NY, USA: John Wiley \& Sons. $808 p$.

Sims, P. L., AND J. S. Singh. 1978. The structure and function of ten western North American grasslands: II intra-seasonal dynamics in primary producer compartments. Journal of Ecology 66:547-572.

Sims, P. L., J. S. Singh, AND W. K. LaUenRoth. 1978. The structure and function of ten western North American grasslands: I abiotic and vegetational characteristics. Journal of Ecology 66:251-285.

Systat Software [Computer Program]. 2007. Systat 12: statistics. Richmond, CA, USA: Systat Software.

Vermeire, L. T., R. B. Mitchell, S. D. Fuhlendorf, and D. B. Wester. 2004. Selective control of rangeland grasshoppers with prescribed fire. Journal of Range Management 57:29-33.

Whelan, R. 1995. The ecology of fire. Cambridge, UK: Cambridge University Press. $360 \mathrm{p}$.

Wright, H. A., And A. W. Balley. 1982. Fire ecology: United States and Southern Canada. New York, NY, USA: John Wiley \& Sons. 528 p.

Wright, H. A., S. C. Bunting, and L. F. Neuenschwander. 1976. Effect of fire on honey mesquite. Journal of Range Management 29:467-471. 